\title{
UJI AKTIVITAS ANTIBAKTERI EKSTRAK ETANOL BIJI MAHONI (Swietenia mahagoni) TERHADAP Shigella dysenteriae
}

\author{
Asiska Permata Dewi 1), Annisa Fauzana ${ }^{2)}$ \\ 1) Analis Farmasi dan Makanan Universitas Abdurrab \\ Jl. Riau Ujung Pekanbaru \\ email : asiska.permata@univrab.ac.id \\ 2) Analis Farmasi dan Makanan Universitas Abdurrab \\ Jl. Riau Ujung Pekanbaru \\ email : annisa.fauzana@univrab.ac.id
}

\begin{abstract}
One of the plants that can be used as traditional medicine is mahogany (Sweitenia mahagoni). The presence of flavonoid compounds in mahogany seeds is suspected as a compound that serves to inhibit bacterial growth. One of the antibacterial effects is to treat diarrhea diseases caused by Shigella dysenteriae. Diarrhea is infectious intestinal disease a public health problem in developing countries. The aim of this research is to know and measure the inhibition zone of ethanol extract of mahogany seed to the growth of Shigella dysenteriae bacteria with concentration $25 \%, 50 \%, 75 \%, 100 \%$. This research is a descriptive study in vitro using disc method. The result of the research has found that the average inhibition zone diameter at $25 \%, 50 \%$, $75 \%, 100 \%$ concentration is $6 \mathrm{~mm}, 8 \mathrm{~mm}, 8.33 \mathrm{~mm}, 10.33 \mathrm{~mm}$. Negative controls do not provide inhibition and positive control yields an average diameter of $21.33 \mathrm{~mm}$. Based on the above results, it can be concluded mahogany seed extract provides resistance to Shigella dysenteriae.
\end{abstract}

Keywords : extract mahogany seed (Swietenia mahagoni), Shigella dysenteriae, diarrhea, power inhibition.

\section{ABSTRAK}

Salah satu tanaman yang dapat dimanfaatkan sebagai obat tradisional adalah biji mahoni (Sweitenia mahagoni). Adanya senyawa flavonoid di dalam biji mahoni diduga sebagai senyawa yang berfungsi menghambat pertumbuhan bakteri. Salah satu efek antibakteri adalah mengobati penyakit diare yang disebabkan oleh Shigella dysenteriae. Diare menrupakan penyakit infeksi usus yang menjadi masalah kesehatan di Negara berkembang termasuk Indonesia. Penelitian ini bertujuan untuk mengetahui dan mengukur zona hambat ekstrak etanol biji mahoni terhadap pertumbuhan bakteri Shigella dysenteriae dengan konsentrasi $25 \%, 50 \%, 75 \%, 100 \%$. Penelitian ini merupakan penelitian deskriptif secara in vitro dengan menggunakan metode cakram. Hasil penelitian yang telah dilakukan didapat diameter rata-rata zona hambat pada konsentrasi $25 \%, 50 \%, 75 \%, 100 \%$ adalah $6 \mathrm{~mm}, 8 \mathrm{~mm}, 8,33 \mathrm{~mm}, 10,33 \mathrm{~mm}$. Kontrol negatif tidak memberikan daya hambat dan kontrol positif menghasilkan diameter rata-rata $21,33 \mathrm{~mm}$. Berdasarkan hasil diatas, dapat disimpulkan ekstrak biji mahoni memberikan daya hambat terhadap Shigella dysenteriae.

Kata Kunci $\quad$ : Ekstrak Biji Mahoni (Swietenia mahagoni), Shigella dysenteriae, Diare, Daya hambat

JOPS-VOLUME I-DEC 2017 


\section{Pendahuluan}

Infeksi merupakan reaksi lokal atau sistemik karena invasi kuman yang masuk ke dalam tubuh. Penyakit infeksi masih merupakan penyebab utama morbiditas dan mortalitas di dunia. Menurut WHO pada tahun 2011, sebanyak 25 juta kematian di seluruh dunia, sepertiganya disebabkan oleh penyakit infeksi. Penyakit infeksi menjadi masalah kesehatan di dunia terutama di negara berkembang karena tingkat pengetahuan dan kesadaran akan pentingnya kesehatan penduduknya masih rendah. Sebagian besar penyakit infeksi tersebut disebabkan oleh bakteri, salah satunya adalah Shigella dysenteriae.

Shigella dysenteriae merupakan bakteri gram negatif, berbntuk basil, fakultatif anaerob, dan tidak berspora. Penyakit yang disebabkan oleh Shigella menyebabkan hampir 167 juta peristiwa diare, dan lebih dari satu juta kematian per tahun yang salah satunya disebabkan oleh spesies Shigella dysenteriae. Obat-obatan berkhasiat antibiotik seperti sulfonamid, tertrasiklin, ampisilin dan trimetoprim-sulfametoksazol saat ini tidak efektif lagi (resistensi) terhadap strain Shigella ${ }^{[1]}$.

Meningkatnya kejadian resistensi bakteri terhadap antibiotik pada umumnya, telah mendorong usaha menemukan antibiotik baru yang lebih efektif, paten, mudah diperoleh, memiliki efek samping ringan, dan tersedia secara kontinyu dalam jumlah yang cukup. Berbagai strategi digunakan oleh para peneliti untuk mencari antibiotika baru melalui sintesis senyawa murni, studi metabolisme spesifik mikroorganisme patogen dan eksplorasi senyawa aktif dari bahan alam atau tanaman obat yang telah digunakan oleh masyarakat untuk mengobati penyakit infeksi ${ }^{[2]}$.

Salah satu tanaman yang digunakan oleh masyarakat luas untuk pengobatan adalah pohon mahoni (Swietenia Mahagoni). Semua bagian dari pohon mahoni dapat dimanfaatkan mulai dari kayu, kulit kayu, daun, dan biji buahnya. Namun yang banyak dimanfaatkan khasiatnya untuk pengobatan adalah biji buah mahoni, diantaranya mengobati hipertensi, kurang nafsu makan, demam, diabetes mellitus, masuk angin, eksim, dan rematik ${ }^{[3]}$. Selain itu, biji mahoni juga berkhasiat antiseptik, antioksidan, dan antimikroba ${ }^{[4]}$.

Penelitian lebih lanjut menunjukkan biji mahoni mengandung senyawa aktif golongan alkaloid, terpenoid, antrakuinon, glikosida jantung, saponin dan minyak atsiri. Beberapa penelitian juga telah dilakukan untuk membuktikan aktivitas farmakologi dari biji mahoni. Falah et al. (2007) melaporkan bahwa biji mahoni terbukti mempunyai aktivitas antioksidan, antimalaria, antidiare, dan antimikroba ${ }^{[5]}$. Soetjipto et al, (2003) juga telah membuktikan bahwa ekstrak biji mahoni memiliki aktivitas antimikroba ${ }^{[6]}$. Dengan demikian, penelitian ini dilakukan untuk mengetahui aktivitas antimikroba ekstrak biji mahoni terhadap Shigella dysenteriae.

\section{Tinjauan Pustaka}

Biji mahoni adalah salah satu obat tradisional yang paling popular. Di daerah afrika pada tahun 70 -an banyak orang mencari biji mahoni karena biji mahoni adalah spesies yang sangat berharga dapat digunakan sebagai obat. Masyarakat di daerah afrika mengkonsumsi biji mahoni hanya dengan menelan bijinya ${ }^{[7]}$.

Biji mahoni mengandung senyawa bioaktif. Hasil penelitian oleh Sahgal et al. (2009) menunjukan bahwa biji mahoni mengandung zat-zat kimia seperti flavonoid, saponin, tannin, glikosida kardiak, minyak atsiri, alkaloid, dan antrakuinon. Flavonoid adalah zat yang paling banyak ditemukan pada biji mahoni. Kandungan biji mahoni adalah minyak atsiri, minyak atsiri merupakan substansi alami yang dikenal dapat menghambat pertumbuhan beberapa jenis bakteri merugikan.. Kandungan minyak atsiri yang diduga mempunyai peranan paling penting dalam menghambat pertumbuhan bakteri adalah fenol yang bersifat bakterisidal. Selain itu, saponin mempunyai peranan paling penting dalam menghambat antimikroba, saponin menunjukkan aktivitas antimikroba ${ }^{[8]}$.

Biji mahoni berkhasiat mengobati tekanan darah tinggi (Hipertensi), kurang nafsu makan, demam, kencing manis (diabetes mellitus), masuk angin, eksim, dan rematik ${ }^{[4]}$. Biji mahoni bisa digunakan sebagai obat yakni penyakit kuli [9]. tSelain itu, biji mahoni juga berkhasiat antiseptik, antioksidan, dan antimikroba ${ }^{[5]}$. Ekstrak biji mahoni dilaporkan memiliki aktifitas farmakologi, termasuk aktivitas antiinflamasi ${ }^{[10]}$.

Shigella dysenteriae merupakan bakteri gram negatif berukuran 0,5-0,7 $\mu \mathrm{m}$. Bentuk morfologi Shigella dysenteriae adalah batang pendek atau basil tunggal, tidak berspora, tidak berflagel sehingga tidak bergerak, dan dapat memiliki kapsul. Shigella dysenteriae tidak membentuk gas pada reaksi fermentasi dan 
lebih rentan terhadap bahan kimia jika dibandingkan dengan Salmonella. Dalam media pembenihan, Shigella dysenteriae membentuk koloni yang halus dan mengkilap. Shigella dysenteriae memiliki daya tahan yang rendah terhadap berbagai zat kimia, berdasarkan reaksi fermentasi, Shigella dysenteriae dapat dibedakan dari spesies Shigella lain karena memberikan hasil negatif pada fermentasi manitol. Dialam bebas bakteri ini dapat bertahan hidup di air laut selama 2-5 bulan ${ }^{[11]}$.

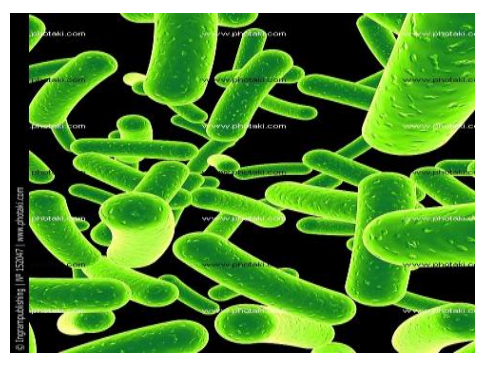

Gambar 1. Bakteri Shigella dysenteriae

\section{Metode Penelitian}

\section{a. Desain penelitian}

Penelitian ini merupakan penelitian deskriptif untuk mengetahui senyawa metabolit sekunder dari biji mahoni dengan cara reaksi warna dan pengendapan menggunakan reagen kimia. Sedangkan uji aktivitas antibakteri ektrak etanol biji mahoni menggunakan metode cakram.

b. Sampel Sampel yang digunakan adalah biji mahoni (Sweitenia mahagoni) yang dibeli di Pasar Pusat, jalan Agus Salim Pekanbaru.

C. Alat dan Bahan Penelitian Alat- Alat

Alat-alat yang digunakan pada penelitian ini adalah: Asbes, autoclove, aluminium foil, batang pengaduk, beaker glass, bola hisap, lampu spritus, cawan petridist, Erlenmeyer, incubator, kapas lidi steril, kawat ose, kertas label, kertas padi, korek api, kompor, labu ukur, penggaris, pinset, pipet tetes, mikro pipe, pipet takar, pisau, rotary evaporator, rak tabung reaksi, spatel, tabung reaksi, timbangan analitik.

\section{Bahan- Bahan}

Skrining fitokimia

Daun mahoni, asam asetat glasial $2 \mathrm{~N}$, air suling, asam sulfat pekat $36 \mathrm{~N}$, asam klorida $2 \mathrm{~N}$ bismut nitrat, kalium iodida, iodium, bubuk magnesium, merkurium (II) Klorida, etanol, dan spritus.

Uji aktivitas antibakteri

Mueller Hinton Agar (MHA). ekstrak biji mahoni 25\%, 50\%, 75\% dan 100\%, strain Staphylococcus epidermidis, aquadest steril, DMSO (dimethyl sulfoxide), Infus $\mathrm{NaCl} 0,9 \%$, disk amoxicillin (kontrol positif), asam sulfat $\left(\mathrm{H}_{2} \mathrm{SO}_{4} 1 \%\right)$, barium klorida hidrat $\left(\mathrm{BaCl}_{2} .2 \mathrm{H}_{2} \mathrm{O} 1,175 \%\right)$, alkohol $70 \%$, etanol $96 \%$, disk kosong dengan diameter $6 \mathrm{~mm}$. 


\section{d. Prosedur Kerja}

\section{Pembuatan Simplisia Biji Mahoni}

Ditimbang $1 \mathrm{~kg}$ biji mahoni lalu dicuci bersih, tiriskan lalu dirajang tipis-tipis, kemudian dianginkan pada suhu kamar sampai kering, lalu ditimbang, dimasukkan simplisia biji mahoni yang telah halus ke dalam wadah.

\section{Skrining fitokimia simplisia biji mahoni}

a. Uji alkaloid. Simplisia biji mahoni sebanyak 0,5 g kemudian ditambahkan $1 \mathrm{ml}$ asam klorida $2 \mathrm{~N}$ dan $9 \mathrm{ml}$ air suling, dipanaskan di atas penangas air selama 2 menit, didinginkan dan disaring. Filtrat yang diperoleh dipindahkan ke dalam tiga tabung reaksi masing-masing sebanyak 3 tetes. Kemudian masing-masing tabung tersebut ditambahkan 2 tetes pereaksi dragendroff, mayer, dan wagner. Apabila terbentuk endapan merah atau jingga menunjukan bahwa sampel tersebut mengandung alkaloid, dengan menggunakan pereaksi dragendroff, dengan pereaksi mayer memberikan endapan berwarna putih atau kuning, dengan pereaksi wagner memberikan endapan berwarna coklat ${ }^{[12]}$.

b. Uji flavonoid. Diambil simplisia sebanyak $200 \mathrm{mg}$ diekstrak dengan $5 \mathrm{ml}$ etanol dan dipanaskan selama 5 menit di dalam tabung reaksi. Selanjutnya ditambah beberapa tetes $\mathrm{HCl}$ pekat $2 \mathrm{~N}$. Kemudian ditambakan $0,2 \mathrm{~g}$ bubuk mg. Hasil positif ditunjukkan dengan timbulnya warna merah tua (magenta) dalam selama 3 menit ${ }^{[12]}$.

c. Uji triterpenoid dan steroid. Diambil simplisia sebanyak 50 - $100 \mathrm{mg}$ ditambahkan asam asetat glasial sampai semua sampel terendam, dibiarkan selama 15 menit kemudian 6 tetes larutan dipindahkan ke dalam tabung reaksi dan ditambahkan $2-3$ tetes $\mathrm{H}_{2} \mathrm{SO}_{4} \mathrm{P}$. Adanya triterpenoid ditunjukkan dengan terjadinya warna merah jingga atau ungu, sedangkan steroida ditunjukkan dengan terbentuknya warna biru ${ }^{[12]}$.

d. Uji saponin. Diambil simplisia sebanyak 2 g dimasukkan ke dalam tabung reaksi, kemudian ditambahkan air suling hingga seluruh sampel terendam, dididihkan selama 2 - 3 menit, dan selanjutnya didinginkan, kemudian dikocok kuat-kuat. Hasil positif ditunjukkan dengan terbentuknya buih yang stabil $10-15$ menit ${ }^{[12]}$.

e. Uji tanin. Diambil simplisia sebanyak $20 \mathrm{mg}$ ditambah etanol sampai sampel terendam semuanya. Kemudian ditambahakan $2-3$ tetes larutan $\mathrm{FeCl}_{3} 1 \%$. Hasil positif ditunjukkan dengan terbentuknya warna hitam kebiruan atau hijau ${ }^{[12]}$.

\section{Uji aktivitas antibakteri}

\section{a. Pembuatan Ekstrak Etanol Biji Mahoni (Sweitenia mahagoni)}

Ditimbang simplisia biji mahoni sebanyak 500 gram, masukkan kedalam beaker glass $500 \mathrm{ml}$, maserasi dalam etanol $96 \%$, tutup dengan aluminium foil, rendam selama 3 hari sambil diaduk, terlindung dari cahaya, maserasi diulang 3 kali, dengan jenis dan jumlah pelarut yang sama, kemudian saring dengan kertas saring, maserat dikumpulkan, pelarut diuapkan dengan rotary evaporator hingga didapatkan ektrak kental $^{[13]}$.

b. Uji Daya Hambat Antibakteri

- Pembuatan Larutan Standar Mc. Farland

Pipet larutan $\mathrm{H}_{2} \mathrm{SO}_{4} 1 \%$ sebanyak $9 \mathrm{ml}$ masukkan kedalam tabung reaksi, tambahkan larutan $\mathrm{BaCl}_{2} 2 \mathrm{H} 2 \mathrm{O} 1,175 \%$ sebanyak $1 \mathrm{ml}$, kemudian dikocok, sampai terbentuk larutan keruh, kekeruhan ini dipakai sebagai standar kekeruhan suspensi bakteri uji.

- Pembuatan Suspensi Bakteri

Dibakar kawat ose menggunakan api bunsen hingga membara, diambil strain bakteri Staphylococcus epidermidis dengan kawat ose, kemudian disuspensikan dalam tabung reaksi yang berisi $\mathrm{NaCl}$ fisiologis, dikocok sampai keruh, dimana kekeruhan sama dengan larutan standar Mc. Farland. 
- Pembuatan Media Pembenih Bakteri Mueller Hinton Agar (MHA)

Ditimbang sebanyak 3,8 gram media Media Mueller Hinton Agar (MHA) dimasukkan kedalam erlenmeyer $250 \mathrm{ml}$, tambahkan $100 \mathrm{ml}$ aquadest sambil dikocok, panaskan hingga mendidih, tutup dengan kapas, masukkan media tersebut kedalam autoclave, tutup autoclave dan klep pipa dengan rapat, sterilkan pada suhu $121^{\circ} \mathrm{C}$ selama 15 menit, setelah cukup waktu maka klep pipa dibuka, maka suhu akan turun sedikit demi sedikit, keluarkan medium MHA (Mueller Hinton Agar) dari autoclave, lalu tuangkan ke dalam masing- masing cawan petridist.

- Pengujian aktivitas antibakteri

Celupkan kapas lidi steril ke dalam suspensi bakteri yang sudah disamakan kekeruhannya dengan Mc.Farland, tunggu sampai meresap kedalam kapas, oleskan kapas lidi tersebut pada media Mueller Hinton Agar (MHA) sampai rata, ambil disk amoxicilin menggunakan pinset sebagai kontrol positif, berikan tekanan sebagai kontrol positif, ambil kertas disk kosong yang berdiameter $6 \mathrm{~mm}$ yang sudah terlebih dahulu disterilkan dengan oven pada suhu $121^{\circ} \mathrm{C}$ selama 15 menit, letakan pada permukaan media, teteskan DMSO steril menggunakan mikro pipet 10 mikroliter sebagai kontrol negatif, ambil kertas disk kosong letakan pada permukaan media, teteskan larutan ekstrak etanol biji mahoni dengan dosis $25 \%$ menggunakan mikro pipet 10 mikroliter, beri tekanan, lakukan juga untuk dosis $50 \%, 75 \%$ dan $100 \%$, kemudian inkubasi dalam inkubator selama $1 \times 24$ jam pada suhu $37^{\circ} \mathrm{C}$. Diukur zona hambat bakteri yang terbentuk.

\section{Hasil Percobaan}

Pada penelitian ini dibuat empat konsentrasi yaitu 25\%, 50\%, 75\%, 100\%, tujuan variasi ini dibuat untuk melihat perbedaan daya hambat dengan berbagai perbedaan konsentrasi. Pengujian ini dilakukan tiga kali pengulangan yang bertujuan untuk mendapatkan hasil yang lebih akurat. Diameter rata-rata zona hambat pada konsentrasi $25 \%, 50 \%, 75 \%, 100 \%$ adalah $6 \mathrm{~mm}, 8 \mathrm{~mm}, 8,33 \mathrm{~mm}, 10,33 \mathrm{~mm}$. Kontrol positif rata-rata zona hambat nya $21,33 \mathrm{~mm}$. Kontrol negatif tidak memberikan daya hambat karena daya hambatnya $6 \mathrm{~mm}$ yang merupakan diameter disk.

Berdasarkan hasil di atas, konsentrasi $100 \%$ daya hambatnya lebih besar dibandingkan konsentrasi $25 \%$, $50 \%, 75 \%$, hal ini disebabkan pada konsentrasi $100 \%$ ekstraknya lebih kental sehingga kandungan metabolit sekundernya lebih banyak dibandingkan konsentrasi $25 \%, 50 \%$, dan $75 \%$. Sedangkan pada konsentrasi $25 \%$ tidak memberikan daya hambat, artinya pada konsentrasi ini tidak dapat menghambat pertumbuhan bakteri. Pada tabel Interprestasi Baku Hambatan Test Kepekaan Kirbi-Bauer terhadap antibiotik kloramfenikol (kontrol positif) menyatakan bahwa diameter zona hambat $<12$ adalah resisten, 13-17 intermidiete, dan $>18$ adalah sensitif. Daya hambat yang dihasilkan kloramfenikol adalah $21,33 \mathrm{~mm}$, jadi kloramfenikol masih sensitif terhadap Shigella dysenteriae. Sedangkan untuk ekstrak pada konsentrasi 25\%, 50\%, 75\% dan 100\% rata-rata diameter zona hambat adalah $6 \mathrm{~mm}$ (diameter disk), $8 \mathrm{~mm}, 8,33 \mathrm{~mm}, 10,33 \mathrm{~mm}$.

Berdasarkan hasil diatas didapat hasil adalah resisten karena <12. Resistensi adalah kemampuan mikroorganisme untuk bertahan terhadap efek antibiotik diantaranya dengan memperoleh gen resisten melalui mutasi atau perubahan plasmid (transfer gen) antara spesies bakteri yang sama ${ }^{[14]}$. 
Tabel I. Hasil uji daya hambat ekstrak etanol biji mahoni (Swietenia Mahagoni) terhadap Shigella dysenteriae

\begin{tabular}{|c|l|c|c|c|c|}
\hline \multirow{2}{*}{ No } & \multicolumn{1}{|c|}{ Sampel } & \multicolumn{2}{|c|}{ Diameter zona hambat (mm) } & \multirow{2}{*}{ Rata-rata } \\
\cline { 3 - 5 } & & I & II & III \\
\hline 1 & Konsentrasi 25\% & $6 \mathrm{~mm}$ & $6 \mathrm{~mm}$ & $6 \mathrm{~mm}$ & $6 \mathrm{~mm}$ \\
\hline 2 & Konsentrasi $50 \%$ & $7 \mathrm{~mm}$ & $7 \mathrm{~mm}$ & $10 \mathrm{~mm}$ & $8 \mathrm{~mm}$ \\
\hline 3 & Konsentrasi 75\% & $8 \mathrm{~mm}$ & $7 \mathrm{~mm}$ & $10 \mathrm{~mm}$ & $8,33 \mathrm{~mm}$ \\
\hline 4 & Konsentrasi 100\% & $11 \mathrm{~mm}$ & $10 \mathrm{~mm}$ & $10 \mathrm{~mm}$ & $10,33 \mathrm{~mm}$ \\
\hline 5 & Kloramfenikol & $22 \mathrm{~mm}$ & $22 \mathrm{~mm}$ & $20 \mathrm{~mm}$ & $21,33 \mathrm{~mm}$ \\
\hline 6 & Aquadest Steril & $6 \mathrm{~mm}$ & $6 \mathrm{~mm}$ & $6 \mathrm{~mm}$ & 6 \\
\hline
\end{tabular}

Ket : $6 \mathrm{~mm}=$ Diameter disk ( Tidak memberikan daya hambat).

Pada pengujian kandungan senyawa metabolit sekunder, biji mahoni mengandung senyawa triterpenoid, saponin, dan tannin. Berdasarkan literatur, senyawa triterpenoid dapat menghambat pertumbuhan atau mematikan bakteri dengan mengganggu proses terbentuknya membrane dan atau dinding sel ${ }^{[15]}$. Jadi, dapat diketahui bahwa daya hambat terhadap bakteri ini disebabkan karena adanya senyawa triterpenoid yang berperan dalam menghambat pertumbuhan bakteri.

Tabel II. Skrining fitokimia biji mahoni.

\begin{tabular}{|c|c|c|c|c|}
\hline No & Kandungan Metabolit & Hasil & Ket & an \\
\hline () & Sekunder & (1) & & - \\
\hline 1 & Triterpenoid & Warna merah & Positif & \\
\hline 2 & Saponin & Berbuih stabil & Positif & \\
\hline 3 & Tanin & Warna Hijau & Positif & \\
\hline 4 & Alkaloid & $\begin{array}{l}\text { Mayer, warna putih keruh } \\
\text { Dragendrof, warna kuning } \\
\text { Wagner, warna coklat }\end{array}$ & Negatif & \\
\hline 5 & Flavonoid & Warna putih keruh & Negatif & \\
\hline
\end{tabular}

\section{Kesimpulan}

Pada penelitian ini, dapat disimpulkan bahwa:

- Uji aktivitas antibakteri ekstrak etanol biji mahoni terhadap Shygella dysentriae pada konsentrasi $25 \%, 50 \%, 75 \%$, dan $100 \%$ adalah $6 \mathrm{~mm}, 8 \mathrm{~mm}, 8,33 \mathrm{~mm}, 10,33$.

- Senyawa metabolit sekunder yang terkandung dalam ekstrak etanol biji mahoni adalah triterpenoid, saponin, dan tannin.

- Senyawa metabolit sekunder yang berperan dalam menghambat bakteri adalah senyawa triterpenoid. 


\section{REFERENSI}

[1] Ervia, 2012 Cit Seidlein et al. 2006, "Uji Aktivitas Antibakteri Kombinasi Ekstrak Etanol Daun Pare (Momordica charantia L.) dan Daun Pepaya (Carica papaya L.) Terhadap Bakteri Shigella dysenteriae ATTCC 9361”, Skripsi, Fakultas Farmasi, Universitas Setia Budi.

[2] Katzung, Bertram G., 2001, "Basic and Clinical Pharmacology Second Edition”, Lange Medical Publications, USA

[3] Agromedia, R., 2008, “Buku Pintar Tanaman Obat”, Jakarta, PT Agromedia Pustaka.

[4] Wahyunita, 2011, “Aktivitas Antibakteri Ekstrak Biji Mahoni dalam Menghambat Pertumbuhan Staphylococcus aureus Secara in-vitro”, Skripsi, Darussalam: Program Studi Kedokteran Universitas Syiah Kuala Darussalam.

[5] Falah, S., Suzuki, T., dan Katayama, T., 2007, "Chemical constituents from Swietenia macrophylla", Bark and their antioxidant activity, Pakistan Biol Sci Vol.11, No.16.

[6] Soetjipto, H., A.I. Kristijanto, F.E.T.Nugroho, 2003, “Aktifitas Antibakteri Ekstrak Flavonoid Biji Mahoni (Sweitenia mahagoni Jacq.)", Prosiding Seminar Nasional Sains dan Pendidikan Sains, Universitas Kristen Satya Wacana.

[7] Sahgal G., Ramanathan S., Susidharaan S., 2009, "Invitro Antioxidant and Xanthine Oxidase Inhibitory Activities of Methanolic Swietinia mahagony Seed Extracts”, International Journal of Green Pharmacy.

[8] Soetan KO, Oyekunle MA, Aiyelaagbe OO. Fafunso MA., 2010, "Evaluation of Antimicrobial Activity of Saponins Extract of Sorhum bicolor L. Mocnch”, African Journal of Biotechnology, Vol.5, No.23, Pp.2405-2407.

[9] Permadi, A., 2008, “Membuat Kebun Tanaman Obat”, Cetakan 1. Jakarta, Pustaka Bunda

[10] Ghosh, S., Shila E.B., Kunal, R., Jayanta K.G., Joseph R., dan Vedesiromoni, 2009, "Pharmacological Effects of Methanolic Ekstract of Swietenia mahagoni Jacq (Metiaceae) Seeds", International Journal of Green Pharmacy.

[11] Radji, M, 2010, "Buku Ajar Mikrobiologi Panduan Mahasiswa Farmasi dan Kedokteran”, Jakarta, EGC

[12] Sangi, M., M.R.J.Runtuwene, H.E.I.Simbala, dan V.M.A.Makang, 2008, “Analisis Fitokimia Tumbuhan Obat di Kabupaten Minahasa Utara", Chem Prog, Vol.1, Manado

[13] Depertemen Kesehatan Republik Indonesia, 1979, “Farmakope Indonesia Edisi III”, Jakarta

[14] Walsh, C. 2003, “Antibiotics: action, origins, resistance, ASM Press”, Washington DC

[15] Ajizah, A, 2004, "Sensitivitas Salmonella Typhimurium Terhadap Ekstrak Daun Psidium Guajava L”, Bioscientiae, Vol.1, No.1, Hal 31-38. 